\title{
Thrombomodulin Is Present in Human Plasma and Urine
}

\author{
Hidemi Ishii and Philip W. Majerus
}

Division of Hematology-Oncology, Departments of Internal Medicine and Biological Chemistry, Washington University School of Medicine, St. Louis, Missouri 63110

\begin{abstract}
Thrombomodulin is an endothelial cell membrane protein that is a cofactor required for the rapid activation of plasma protein C. We now report that plasma and urine of normal subjects contains a modified form of thrombomodulin that is soluble. The levels measured by radioimmunoassay were $292 \pm 60 \mathrm{ng}$ thrombomodulin/ml plasma and $102 \pm 38 \mathrm{ng}$ thrombomodulin/ml urine. Thrombomodulin was isolated from both plasma and urine by immunoaffinity chromatography using a polyclonal anti-human thrombomodulin IgG column. The apparent molecular weight of soluble thrombomodulin was estimated by immunoblot analysis using ${ }^{125}$ I-monoclonal anti-thrombomodulin IgG. When run without 2-mercaptoethanol, soluble thrombomodulin appeared as two polypeptides, $M_{\mathrm{r}}=63,000$ and 54,000 , while samples run with 2-mercaptoethanol migrated mainly at $M_{r}=85,000$. These results imply that the soluble form of thrombomodulin is smaller than the cellular form, presumably because of a lack of the membrane-binding domain. Soluble thrombomodulin is similar to cellular thrombomodulin in its intrinsic protein $\mathrm{C}$-activating cofactor activity as measured by antibody neutralization. The apparent $K_{m}$ for protein $C$ was the same for cellular and soluble thrombomodulin, while the soluble form requires a higher concentration of thrombin (three- to fivefold) for one-half maximal activity than the cellular form. Thrombomodulin functional activity cannot be directly measured in plasma because of some inhibitory substance(s). The physiological significance of circulating and urinary thrombomodulin is presently obscure.
\end{abstract}

\section{Introduction}

Protein C is a vitamin K-dependent glycoprotein of $62,000 \mathrm{~mol}$ $w t$, which circulates in human plasma at a concentration of $\sim 4$ $\mu \mathrm{g} / \mathrm{ml}$ (1). Protein $\mathrm{C}$ is converted to a protease with anticoagulant function by thrombin. The conversion requires an endothelial cell membrane protein cofactor, thrombomodulin, which was first isolated from rabbit lung (2). We have isolated the human form of thrombomodulin from placenta (3) and lung (4) and have prepared both polyclonal (3) and monoclonal (5) antibodies directed against the protein. We have shown that thrombomodulin is widely distributed on the endothelium of human arteries, veins, capillaries, and lymphatics in all organs except

Address correspondence to Dr. Majerus, Division of Hematology-Oncology, Washington University School of Medicine, 660 South Euclid, St. Louis, MO 63110.

Received for publication 22 July 1985.

J. Clin. Invest.

(c) The American Society for Clinical Investigation, Inc.

$0021-9738 / 85 / 12 / 2178 / 04 \$ 1.00$

Volume 76, December 1985, 2178-2181 brain $(6,7)$. The greatest content of thrombomodulin is in lung and placenta as measured by radioimmunoassay of extracts of these tissues (7). We now report that human plasma and urine contain a soluble form of thrombomodulin that has been detected by both radioimmunoassay and by a functional assay.

\section{Methods}

Except where indicated, all reagents were from Sigma Chemical Co., St. Louis, MO. Protein C (8), thrombin (9), and antithrombin III (10) were isolated from human plasma. Human thrombomodulin was isolated from placenta as previously reported (3). Polyclonal anti-human thrombomodulin antibody (3) and mouse monoclonal anti-thrombomodulin antibody (5) were prepared using placental thrombomodulin as the antigen (3). The iodination of thrombomodulin was performed as previously described (7). The iodination of protein A was performed according to Mellman and Unkeless (11). Free ${ }^{125}$ I was removed by chromatography on a 1-ml column of Sephadex G-25. Protein concentration was measured using the Bio-Rad assay (Bio-Rad Laboratories, Richmond, CA) with human IgG as a standard.

Immunoaffinity chromatography. Anti-human thrombomodulin IgG agarose was prepared by coupling $10 \mathrm{mg}$ of rabbit anti-human thrombomodulin $\operatorname{lgG}(10 \mathrm{mg} / \mathrm{ml})$ in $0.1 \mathrm{M}$ morpholino-ethane-sulfonic acid, pH 6.5, to $1 \mathrm{ml}$ of Affi-gel 10 (Bio-Rad Laboratories) overnight at $4^{\circ} \mathrm{C}$. Residual active esters were blocked by the addition of $0.1 \mathrm{ml}$ of $1 \mathrm{M}$ ethanolamine, $\mathrm{pH} 8.0$, for $6 \mathrm{~h}$. The gel was washed with $20 \mathrm{vol}$ of 20 $\mathrm{mM}$ Tris, $\mathrm{pH} 7.4$, containing $0.15 \mathrm{M} \mathrm{NaCl}$ and $0.2 \%$ Nonidet- 40 , and 10 vol of $20 \mathrm{mM}$ Tris, pH 7.4, containing $2 \mathrm{M} \mathrm{NaSCN}, 0.15 \mathrm{M} \mathrm{NaCl}$, and $0.2 \%$ Nonidet -40 . The gel was finally equilibrated with $20 \mathrm{mM}$ Tris, pH 7.4 , containing $0.15 \mathrm{M} \mathrm{NaCl}, 0.2 \%$ Nonidet- 40 , and $0.02 \%$ sodium azide. $60-\mathrm{ml}$ samples of urine and plasma were dialyzed against $20 \mathrm{mM}$ Tris, $\mathrm{pH} 7.4$, containing $10 \mathrm{mM}$ benzamidine, $0.15 \mathrm{M} \mathrm{NaCl}$, and $0.2 \%$ Nonidet-40. The dialyzed urine and plasma were applied to separate $0.5-\mathrm{ml}$ columns of the anti-thrombomodulin IgG at $3 \mathrm{ml} / \mathrm{h}$ at $4^{\circ} \mathrm{C}$. After washing with $15 \mathrm{ml}$ of the equilibrating buffer, thrombomodulin was eluted with $20 \mathrm{mM}$ Tris, $\mathrm{pH} 7.4$, containing $2.0 \mathrm{M} \mathrm{NaSCN}$ and $0.2 \%$ Nonidet-40. Fractions $(0.5 \mathrm{ml})$ were collected, dialyzed against $100 \mathrm{vol}$

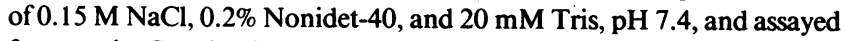
for protein $\mathrm{C}$-activating cofactor activity and for thrombomodulin by radioimmunoassay.

Radioimmunoassay. The radioimmunoassay of thrombomodulin was performed as previously reported (7). Reaction mixtures contained the following: test sample, $0.25 \mu \mathrm{g}$ of anti-thrombomodulin IgG, and $0.5 \mu \mathrm{l}$ of nonimmune rabbit serum in $20 \mathrm{mM}$ Tris, $\mathrm{pH} 7.4$, containing $0.15 \mathrm{M}$ $\mathrm{NaCl}$ and $0.2 \%$ Nonidet -40 , in $0.2 \mathrm{ml}$. After incubation at $4^{\circ} \mathrm{C}$ in 1.5 $\mathrm{ml}$ Eppendorf tubes (Brinkman Instruments Co., Westbury, NY) for 2 h, $2 \mathrm{ng}$ of ${ }^{125}$ I-thrombomodulin $(16,000 \mathrm{cpm}, 8000 \mathrm{cpm} / \mathrm{ng})$ was added and the incubation was continued for an additional $16 \mathrm{~h}$. A $10 \%$ suspension of Staphylococcus aureus (Pansorbin, Calbiochemical-Behring Corp., San Diego, CA) in $0.1 \mathrm{ml}$, was then added to each reaction mixture. Incubation was continued for an additional $1 \mathrm{~h}$ at room temperature. The $S$. aureus organisms were collected by centrifugation at $14,000 \mathrm{~g}$ for $10 \mathrm{~min}$, the supernatant was removed, and the ${ }^{125} \mathrm{I}$-thrombomodulin bound was measured in a gamma scintillation spectrometer.

Cofactor activity of thrombomodulin. Reaction mixtures contained the following: $0.5 \mu \mathrm{M}$ protein $\mathrm{C}, 40 \mathrm{nM}$ thrombin, and a sample in a total vol of $30 \mu$ l containing $20 \mathrm{mM}$ Tris, pH 7.4, $0.15 \mathrm{M} \mathrm{NaCl}, 1 \mathrm{mM}$ 
$\mathrm{CaCl}_{2}$, and $5 \mathrm{mg}$ bovine serum albumin $/ \mathrm{ml}$. Protein $\mathrm{Ca}$ formed was measured as described previously (3).

Immunoblot of thrombomodulin. Sodium dodecyl sulfate-polyacrylamide gel electrophoresis was performed by the method of Laemmli (12) using $4 \%$ acrylamide in the stacking and $10 \%$ acrylamide in the running gel. Samples of thrombomodulin from urine, and plasma were electrophoresed with and without 2-mercaptoethanol. Immunoblotting was performed by the method of Burnette (13). The thrombomodulin was detected by two methods. In one method, polyclonal anti-thrombomodulin serum was used at a 1:250 dilution and detection was made using ${ }^{125}$ I-protein A and autoradiography. The other method used ${ }^{125}$ I-monoclonal anti-thrombomodulin IgG for direct detection of thrombomodulin.

\section{Results}

Properties of plasma and urine thrombomodulin. In preliminary studies we assayed samples of human urine and plasma for thrombomodulin antigen as described below. In these experiments we consistently detected thrombomodulin antigen in both fluids even though we could not detect thrombomodulin activity by protein $\mathrm{C}$-activating cofactor assay of the fluids. To definitively establish that thrombomodulin was actually contained in both plasma and urine, we performed immunoaffinity chromatography as described in methods. The eluates of both plasma and urine were found to have protein $\mathrm{C}$-activating cofactor activity that was linear with time and completely dependent on both protein $\mathrm{C}$ and thrombin. The protein $\mathrm{C}$ dependence of urine thrombomodulin is shown in Fig. 1. Similar results were obtained using thrombomodulin isolated from plasma. The apparent Michaelis constant $\left(K_{\mathrm{m}}\right)$ for protein C was $2 \mu \mathrm{M}$ for both cellular and soluble thrombomodulin. The effect of varying thrombin concentration on thrombomodulin functional activity is shown in Fig. 2. Plasma thrombomodulin had an apparent $K_{\mathrm{m}}$ for thrombin of $1.1 \mathrm{nM}$ compared with $0.33 \mathrm{nM}$ for cellular throm-

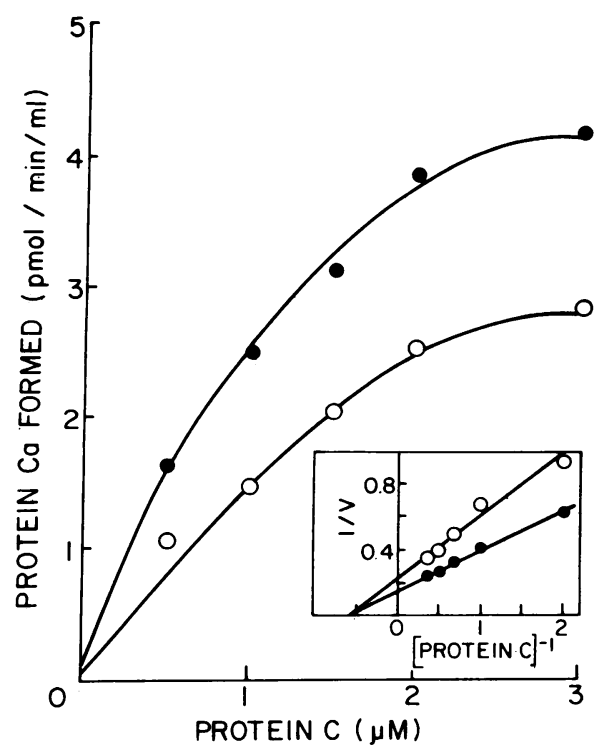

Figure 1. Activation of protein $\mathrm{C}$ by thrombin-thrombomodulin complex. Reaction mixtures $(30 \mu \mathrm{l})$ contained $1.25 \mathrm{nM}$ tissue thrombomodulin standard (- $\bullet-)$, or $10 \mu \mathrm{l}$ of fraction of urine thrombomodulin from anti-thrombomodulin IgG agarose column (- $\left.{ }^{-}\right), 40 \mathrm{nM}$ thrombin, and the indicated concentrations of protein $\mathrm{C}$. Inset shows double-reciprocal plot for the same data. The $K_{\mathrm{m}}$ for protein C was 2 $\mu \mathrm{M}$.

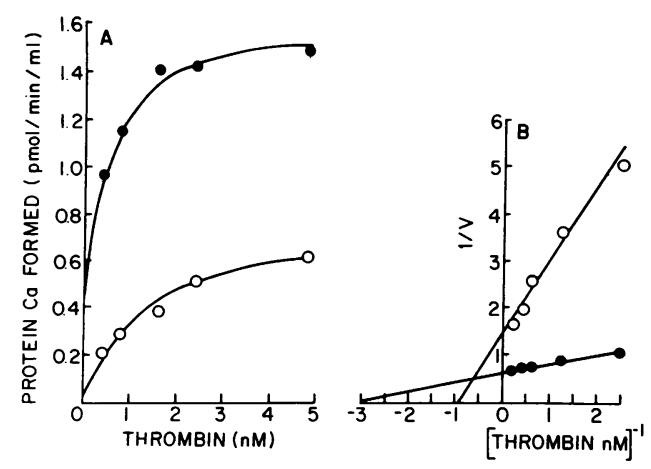

Figure 2. Thrombin dependence of protein $\mathrm{C}$ activation. $A$ shows saturation curve. Reaction mixtures $(30 \mu \mathrm{l})$ contained $1.25 \mathrm{nM}$ tissue thrombomodulin standard (- $\bullet-)$, or $10 \mu$ l of fraction of plasma thrombomodulin from anti-thrombomodulin IgG agarose column $(-\bigcirc-), 0.5 \mu \mathrm{M}$ protein $\mathrm{C}$, and the indicated concentrations of thrombin. $B$ shows double-reciprocal plot of the same data. The $K_{\mathrm{m}}$ of standard and urine thrombomodulin was 0.33 and $1.1 \mathrm{nM}$, respectively.

bomodulin. Urine thrombomodulin had an apparent $K_{\mathrm{m}}$ for thrombin of $1.6 \mathrm{nM}$ (data not shown). The protein C-activating cofactor activity isolated from plasma and urine reflected thrombomodulin as evidenced by the finding that the activity in both cases was completely inhibited by an excess of rabbit anti-thrombomodulin IgG. The relative catalytic activity of urine thrombomodulin vs. cellular thrombomodulin was estimated by the immunotitration experiment shown in Fig. 3. We estimate that urine thrombomodulin has $\sim 2 / 3$ the activity of cellular thrombomodulin based on the finding that the tangent to the inactivation curve of each thrombomodulin extrapolates to the same point using $\sim 2 / 3$ as much urine as cellular thrombomodulin. A similar result was obtained using plasma thrombomodulin as shown in Fig. 4. In this experiment plasma thrombomodulin had $\sim 1 / 2$ the intrinsic activity of that observed using cellular thrombomodulin. We next compared plasma thrombomodulin to cellular thrombomodulin by immunoblot analysis using ${ }^{125}$ I-monoclonal anti-thrombomodulin IgG for detection as shown in Fig. 5. This gel was run in the presence of 2-mercaptoethanol where cellular thrombomodulin has an apparent molecular weight of 105,000 . The major polypeptide detected in plasma thrombomodulin has an apparent molecular weight of 85,000 . The bands detected at lower molecular weights most

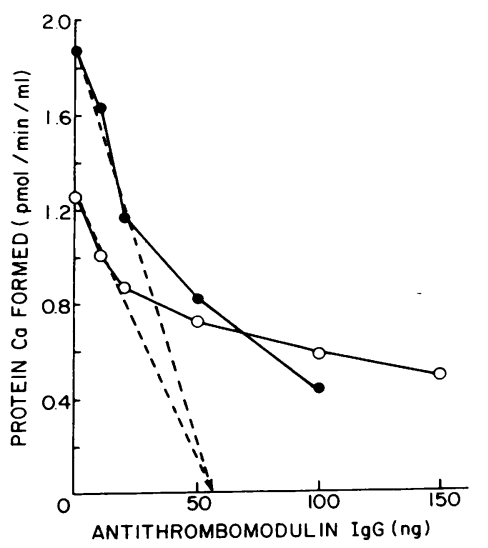

Figure 3. Inhibition of tissue or urine thrombomodulin by anti-human-thrombomodulin rabbit IgG. Tissue (0.94 $\mathrm{ng},-\bullet-)$ and urine (an eluate fraction from anti-thrombomodulin, $10 \mu \mathrm{l},-\mathrm{O}^{-)}$thrombomodulin were incubated with 0 $150 \mathrm{ng}$ polyclonal anti-human-thrombomodulin rabbit IgG for $15 \mathrm{~min}$ at $37^{\circ} \mathrm{C}$. The cofactor activity of thrombomodulin in protein $C$ activation was assayed as described in Methods. In control experiments it was shown that the anti-thrombomodulin IgG does not interfere with protein $\mathrm{Ca}$. 


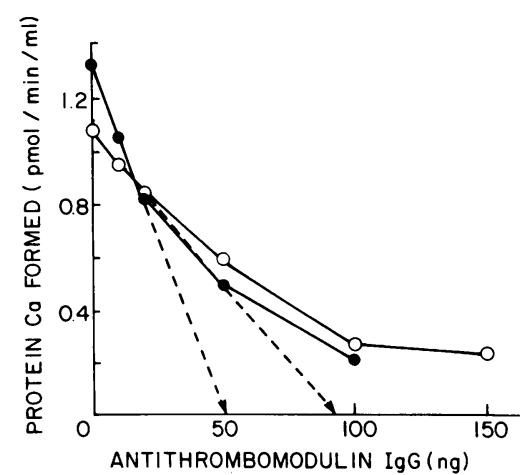

Figure 4. Inhibition of tissue or plasma thrombomodulin by anti-human-thrombomodulin rabbit IgG. Tissue $(0.63 \mathrm{ng},-\bullet-)$ and plasma thrombomodulin (an eluate fraction from anti-thrombomodulin IgG column, $\left.10 \mu \mathrm{l},-\mathrm{O}^{-}\right)$were incubated with $0-150 \mathrm{ng}$ polyclonal antithrombomodulin rabbit $\mathrm{IgG}$ for $15 \mathrm{~min}$ at $37^{\circ} \mathrm{C}$. The cofactor activity of thrombomodulin in protein $\mathrm{C}$ activation was assayed as described in Methods.

likely reflect further degradation products of thrombomodulin. Since one of the lower molecular weight peptides detected in lane 2 migrated similarly to the heavy chain of $\mathrm{IgG}$, we considered the possibility that these peptides might reflect, in part, low affinity binding of ${ }^{125} \mathrm{I}$-anti-thrombomodulin to IgG that eluted from the affinity column. We ran $5 \mu \mathrm{g}$ of human IgG in lane 3 which is slightly detected by the monoclonal anti-thrombomodulin. The amount of thrombomodulin applied to the gel in lane 2 was $7 \mathrm{ng}$ based on functional activity and the protein in this sample was $<2 \mu \mathrm{g}$ by Bio-Rad protein assay. Thus the bands detected in lane 2 reflect a much smaller amount of protein than the IgG in lane 3 . We therefore conclude that the material detected in lane 2 reflects peptides derived from thrombomodulin. We also performed immunoblots on samples electrophoresed in the absence of 2-mercaptoethanol. Under this condition both soluble and cellular thrombomodulin contain high molecular weight peptides that do not run as sharp bands. There is a discrete protein migrating with apparent molecular weight of 75,000 in cellular thrombomodulin. In the plasma thrombomodulin there were two discrete bands detected with apparent molecular weights of 63,000 and 54,000 .

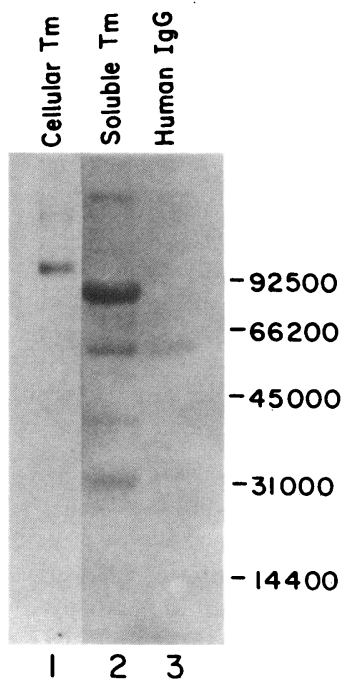

Figure 5. Immunoblot analysis of thrombomodulin. Immunoblot for plasma thrombomodulin. The immunoblot was performed as described in Methods. ${ }^{125}$ I-monoclonal anti-thrombomodulin IgG was used for detection. Lane 1 , isolated tissue thrombomodulin $(1.0 \mu \mathrm{g})$; lane 2 , immunoaffinity-isolated plasma thrombomodulin $(100 \mu \mathrm{l})$; lane 3 , human IgG $(5 \mu \mathrm{g})$.

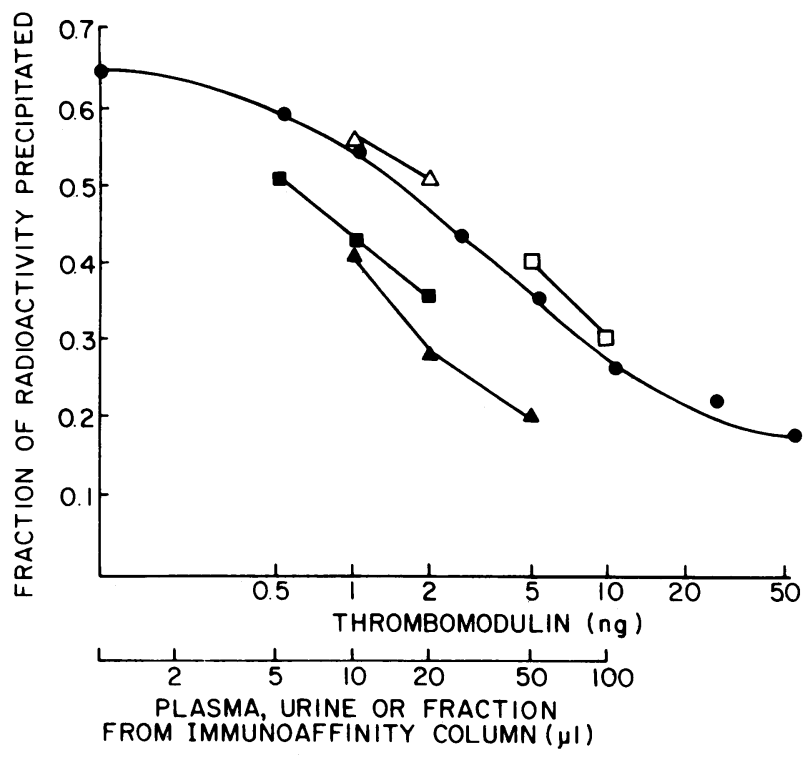

Figure 6. Radioimmunoassay of thrombomodulin. Radioimmunoassay of thrombomodulin was carried out as described in Methods. (•) Standard placenta thrombomodulin, (A) urine concentrated 10 times, $(\triangle)$ plasma, $(\Delta)$ affinity purified urine thrombomodulin, ( $\square$ ) affinity purified plasma thrombomodulin.

Radioimmunoassay of plasma and urine thrombomodulin. A standard curve of the radioimmunoassay of thrombomodulin using isolated placental thrombomodulin is shown in Fig. 6. Assays of urine, plasma, and affinity-purified materials from both sources are also shown and all appear to have similar slopes. We also added known amounts of placental thrombomodulin to both plasma and urine, and showed that there was good recovery of the added material, further indicating that thrombomodulin is accurately measured. We determined the content of thrombomodulin in the urine and plasma of normal subjects as shown in Table I. We have also measured thrombomodulin antigen in serum and find levels identical to those in plasma. In order to exclude the possibility that soluble thrombomodulin was not truly soluble but was contained in fragments of membrane, we subjected serum to ultracentrifugation at $150,000 \mathrm{~g}$ for $1 \mathrm{~h}$ and carried out a radioimmunoassay of the supernatant fraction. All of the thrombomodulin antigen remained in the supernatant, indicating that the material is actually soluble.

Table I. Thrombomodulin Content in Urine and Plasma of Normal Human Subjects

Thrombomodulin

$\begin{array}{ll} & n g / m l \\ \text { Urine }(n=9) & 102 \pm 39 \\ \text { Plasma }(n=6) & 292 \pm 60\end{array}$

The content of thrombomodulin was measured by radioimmunoassay as described in Methods. Samples were obtained from normal subjects aged 25-48. Six men and three women provided urine samples. All of the plasma samples were from men. 


\section{Discussion}

We have found that human plasma and urine contain soluble forms of thrombomodulin that appear to be smaller than cellular thrombomodulin. The origin of this material is presently unclear. We have considered two major possibilities to explain the findings: (a) The soluble circulating forms of thrombomodulin are produced in some cell specifically for secretion into plasma and the molecule functions to promote protein $\mathrm{C}$ activation in the circulation. According to this hypothesis soluble thrombomodulin might be synthesized without the appropriate membrane binding domain to allow its insertion into membranes. (b) The second possibility is that the circulating forms of thrombomodulin reflect proteolysis of endothelial membrane thrombomodulin that is produced either as a result of the normal turnover of thrombomodulin or as a result of endothelial damage in areas of endothelial injury or inflammation. We have noticed that elastase treatment of isolated placental thrombomodulin generates peptides that migrate on sodium dodecyl sulfate gels similarly to circulating thrombomodulin (unpublished observations). It is estimated that adult man has approximately $6 \times 10^{13}$ endothelial cells (14). If the average content of thrombomodulin is 40,000 molecules/cell as we find on cultured umbilical vein endothelial cells (5), then the total content of thrombomodulin in endothelium is $\sim 300 \mathrm{mg}$. Circulating thrombomodulin would total $\sim 0.8 \mathrm{mg}(0.3 \mu \mathrm{g} / \mathrm{ml} \times 2600 \mathrm{ml}$ plasma $)$. Thus the proteolysis of a small fraction of cellular thrombomodulin could conceivably account for the circulating form. We cannot estimate this fraction since the plasma circulation time of soluble thrombomodulin is unknown. We also do not know the source of urinary thrombomodulin. It appears essentially identical to plasma thrombomodulin by immunoblotting, suggesting that it is probably derived from plasma. We also do not know why we are unable to measure directly thrombomodulin activity by protein $\mathrm{C}$ activation assay in plasma. The material isolated from plasma by immunoaffinity chromatography is nearly fully active; however, the yield of material purified from plasma is only $2-5 \%$. The low yield could result from the very small amount of protein involved, which may be lost during chromatography or the subsequent dialysis after elution from the affinity column to remove NaSCN. Alternatively, it may be that most of the immunoassayed thrombomodulin in plasma is degraded to inactive forms that do not bind sufficiently tightly to the affinity column to be recovered upon purification. Furthermore, it is difficult to measure protein $\mathrm{C}$ activation directly in plasma since antithrombin III inhibits thrombin relatively rapidly.

The finding that thrombomodulin exists in a form that is both soluble and functionally active has potential therapeutic implications. Thus, if the structure of soluble thrombomodulin can be determined, it may be possible to produce large amounts of this moiety by molecular cloning techniques. Such a protein could be used as a natural anticoagulant that could inhibit thrombus formation in pathological states.

\section{Acknowledgments}

We thank Dr. Ikuro Maruyama, Dr. Thomas M. Connolly, and Dr. David B. Wilson for helpful discussions.

\section{References}

1. Kisiel, W. 1979. Human plasma protein C. Isolation, characterization, and mechanism of activation by $\alpha$-thrombin. J. Clin. Invest. 64: 761-769.

2. Esmon, N. L., W. G. Owen, and C. T. Esmon. 1982. Isolation of membrane-bound cofactor for thrombin-catalyzed activation of protein C. J. Biol. Chem. 257:859-864.

3. Salem, H. H., I. Maruyama, H. Ishii, and P. W. Majerus. 1984. Isolation and characterization of thrombomodulin from human placenta. J. Biol. Chem. 259:12246-12251.

4. Maruyama, I., H. H. Salem, H. Ishii, and P. W. Majerus. 1985. Human thrombomodulin is not an efficient inhibitor of procoagulant activity of thrombin. J. Clin. Invest. 75:987-991.

5. Maruyama, I., and P. W. Majerus. 1985. The turnover of thrombinthrombomodulin complex in cultured human umbilical vein endothelial cells and A549 lung cancer cells: endocytosis and degradation of thrombin. J. Biol. Chem. In press.

6. Maruyama, I., C. E. Bell, and P. W. Majerus. 1985. Thrombomodulin is found on endothelium of arteries, veins, capillaries, lymphatics, and on syncytiotrophoblast of human placenta. 'J. Cell Biol. 101:363-371.

7. Ishii, H., H. H. Salem, C. E. Bell, E. B. Laposata, and P. W. Majerus. 1986. Thrombomodulin, an endothelial anticoagulant protein, is absent from human brain. Blood. In press.

8. Suzuki, K., J. Stenflo, B. Dahlback, and A. Toedorsson. 1983. Inactivation of human coagulation factor $\mathrm{V}$ by activated protein $\mathrm{C} . \mathrm{J}$. Biol. Chem. 258:1914-1920.

9. Miletich, J. P., C. M. Jackson, and P. W. Majerus. 1978. Properties of the factor Xa binding site on human platelets. J. Biol. Chem. 253: 6908-6916.

10. Owen, W. G. 1975. Evidence for the formation of an ester between thrombin and heparin cofactor. Biochim. Biophys. Acta. 405:380-387.

11. Mellman, I. S., and J. C. Unkeless. 1980. Purification of a functional mouse $\mathrm{Fc}$ receptor through the use of monoclonal antibody. $J$. Exp. Med. 152:1048-1069.

12. Laemmli, V. K. 1970. Cleavage of structural proteins during the assembly of the head of bacteriophage T4. Nature (Lond.). 227:680-685.

13. Burnette, W. N. 1981. "Western blotting": electrophoretic transfer of proteins from sodium dodecyl sulfate-polyacrylamide gels to unmodified nitrocellulose and radiographic detection with antibody and radioiodinated protein A. Anal. Biochem. 112:195-203.

14. Wolinsky, H. 1980. A proposal linking clearance of circulating lipoproteins to tissue metabolic activity as a basis for understanding atherogenesis. Circ. Res. 47:301-311. 